GOSPODARKA SUROWCAMI MINERALNYMI - MINERAL RESOURCES MANAGEMENT

2015 Volume $31 \quad$ Issue $1 \quad$ Pages 141-154

DOI 10.1515/gospo-2015-0004

\title{
Dobór nastaw regulatora PI w układach regulacji procesów wzbogacania węgla
}

\section{Wprowadzenie}

Jednym z podstawowych zadań układu regulacji jest utrzymywanie wartości wielkości regulowanej (wyjściowej procesu) na żądanym poziomie. Ważne z punktu widzenia jakości regulacji jest także uzyskanie właściwego przebiegu wielkości regulowanej oraz ograniczenie wpływu zakłóceń działających na układ. Spełnienie tych wymagań związane jest $\mathrm{z}$ odpowiednim doborem struktury regulatora oraz jego nastaw. W wielu metodach doboru nastaw regulatora wykorzystuje się charakterystyki dynamiczne sterowanego procesu (model dynamiczny obiektu sterowania). Opis właściwości dynamicznych procesu za pomocą modelu matematycznego jest pomocny przy projektowaniu układu sterowania.

Znając model dynamiczny, a także jego parametry, można analitycznie wyznaczyć nastawy regulatora dla przyjętego kryterium jakości regulacji. Różne procesy charakteryzujące się takimi samymi właściwościami dynamicznymi można opisać modelem dynamicznym o takiej samej strukturze, różniącym się tylko wartościami parametrów. Takie podejście daje możliwość zastosowania tego samego typu regulatora w układach regulacji różnych procesów przemysłowych. Odnosi się to także do procesów wzbogacania węgla.

Wiele procesów wzbogacania węgla charakteryzuje się właściwościami dynamicznymi obiektu inercyjnego pierwszego rzędu (opisanego stałą czasową T), z czasem opóźnienia $\tau$. Funkcję przejścia takiego układu w postaci operatorowej możemy zapisać jako:

* Dr hab. inż., prof. nadzw., Politechnika Śląska, Katedra Elektryfikacji i Automatyzacji Górnictwa, Gliwice; e-mail: rkaula@polsl.pl 


$$
\mathrm{Y}(\mathrm{s})=\frac{\mathrm{ke}}{\mathrm{sT}+1} \mathrm{U}(\mathrm{s})
$$

$\Leftrightarrow \mathrm{Y}(\mathrm{s})$ - wielkość wyjściowa obiektu sterowania,

$\mathrm{U}(\mathrm{s})$ - wielkość wejściowa obiektu sterowania,

$\mathrm{k} \quad-$ wzmocnienie obiektu.

Wyniki badań dotyczących dynamiki procesu flotacji węgla były przedstawione w wielu pracach (Joostberens 2011; Kalinowski 1991; Kalinowski, Kaula 2000). Na ich podstawie można stwierdzić, że dynamika procesu flotacji dla obiektu o jednym wejściu sterującym $\mathrm{U}(\mathrm{s})$ (natężenie przepływu odczynnika flotacyjnego) oraz jednym wyjściu Y(s) (zawartość popiołu w odpadach flotacyjnych), może być przedstawiona za pomocą modelu o właściwościach elementu inercyjnego z opóźnieniem czasowym.

Przyjmuje się, że funkcje przejścia podstawowych sygnałów osadzarki można także opisać za pomocą elementu inercyjnego pierwszego rzędu z opóźnieniem (Cierpisz 1980, 2012). Na przykład charakterystykę dynamiczną strefy odbioru produktu dolnego w osadzarce można opisać wzorem (1), przy czym wielkością wyjściową Y(s) jest gęstość rozdziału w osadzarce natomiast wielkością wejściową $U(s)$ - natężenie przepływu produktu dolnego.

Rozważmy proces produkcji mieszanek węgla z dwóch składników: koncentratu o określonej zawartości popiołu i węgla surowego. W układzie tym wielkością wyjściową Y(s) jest zawartość popiołu w mieszance, a wielkością wejściową $U(\mathrm{~s})$ natężenie przepływu węgla surowego. Z punktu widzenia dynamiki omawiany układ technologiczny (Cierpisz 2003) jest szeregowym połączeniem członu inercyjnego (odpowiednio dozowane składniki mieszanki) i opóźnienia transportowego (transport materiału na przenośniku taśmowym). Wobec tego funkcję przejścia obiektu opisującą jego dynamikę, dla zależności wyjścia-wejścia, można opisać wzorem (1).

Regulatory PI (proporcjonalno-całkujący) oraz PID (proporcjonalno-całkująco-różniczkujący) są stosowane w wielu procesach przemysłowych. Szerokie zastosowanie tych regulatorów wynika z wielu zalet, którymi się charakteryzują. Najważniejsze z nich to dobre właściwości kompensacji zakłóceń występujących w procesach przemysłowych oraz prosta budowa tych regulatorów (a zatem łatwa implementacja). Wybór struktury PI albo PID regulatora zależy od właściwości dynamicznych sterowanego procesu, zakłóceń oddziałujących na ten proces oraz wymagań stawianych układowi regulacji, scharakteryzowanych wskaźnikami jakości regulacji (PN-88/M-42000).

Ze względu na szereg zakłóceń występujących w procesach przeróbczych węgla stosowanie członu różniczkującego regulatora PID powinno być ograniczone, na przykład do stabilizacji wybranych parametrów w sterowaniu lokalnym. Celowym rozwiązaniem wydaje się zastosowanie struktury PI regulatora w układzie regulacji. 


\section{Wybrane metody doboru nastaw regulatora PI}

Na rysunku 1 przedstawiono schemat blokowy układu regulacji z wyszczególnionymi podstawowymi elementami przedstawionymi w postaci operatorowej.

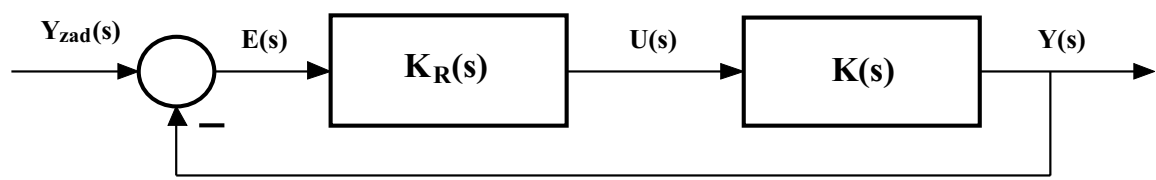

Rys. 1. Schemat blokowy układu regulacji

Fig. 1. Block diagram of control system

Transmitancja obiektu K(s) opisuje dynamikę procesu, zgodnie ze wzorem 1. Regulator PI ma strukturę podaną za pomocą transmitancji $\mathrm{K}_{\mathrm{R}}(\mathrm{s})$ :

$$
\mathrm{K}_{\mathrm{R}}(\mathrm{s})=\mathrm{k}_{\mathrm{r}}\left(1+\frac{1}{\mathrm{~T}_{\mathrm{i}} \mathrm{s}}\right)=\mathrm{k}_{\mathrm{r}}\left(1+\frac{\mathrm{T}_{\mathrm{i}} \mathrm{s}+1}{\mathrm{~T}_{\mathrm{i}} \mathrm{s}}\right)
$$

$\Leftrightarrow \mathrm{k}_{\mathrm{r}}-$ wzmocnienie członu proporcjonalnego,

$\mathrm{T}_{\mathrm{i}}$ - czas zdwojenia członu całkującego.

Zatem transmitancja układu zamkniętego w postaci operatorowej ma postać:

$$
\mathrm{K}_{\mathrm{zam}}(\mathrm{s})=\frac{\mathrm{K}(\mathrm{s}) \mathrm{K}_{\mathrm{R}}(\mathrm{s})}{1+\mathrm{K}(\mathrm{s}) \mathrm{K}_{\mathrm{R}}(\mathrm{s})}
$$

W celu uzyskania odpowiedniej jakości regulacji procesu ważnym zagadnieniem jest dobór parametrów regulatora. Jedną z podstawowych metod doboru regulatora PI, o transmitancji podanej wzorem 2 przyjmuje, się metodę Zieglera-Nicholsa testu identyfikacyjnego (Ziegler i Nichols 1942). W metodzie tej dynamikę procesu (nawet złożonych układów wyższych rzędów) w przybliżeniu opisuje się układem inercyjnym pierwszego rzędu z opóźnieniem. Zatem dla wielu procesów wzbogacania węgla, których dynamika ma właściwości układu inercyjnego pierwszego rzędu z opóźnieniem, metoda Z-N może być wstępną metodą doboru nastaw.

Wielu autorów, zajmujących się doborem nastaw parametrów regulatorów PI dla procesów o dynamice obiektu inercyjnego pierwszego rzędu z opóźnieniem, proponuje nastawy oparte na redukcji stałej czasowej (O’Dwyer 2003). W metodach tych przyjmuje się, że parametr $T_{i}$, członu całkującego regulatora, jest równy stałej czasowej obiektu $T_{i}=T$. Różnice $\mathrm{w}$ nastawach wynikają $\mathrm{z}$ przyjętych kryteriów doboru parametru $\mathrm{k}_{\mathrm{r}}$. Jedno 
z podstawowych kryteriów stosowanych do doboru nastaw związane jest charakterem przebiegu przejściowego wielkości regulowanej.

W pracy dokonano porównania wyników regulacji stabilizacyjnej dla nastaw regulatora PI, wyznaczonych trzema różnymi metodami: metodą Zieglera-Nicholsa (ZN), metodą redukcji stałej czasowej z warunkiem dotyczącym przebiegu wielkości regulowanej (R) oraz metodą bezpośrednią z warunkiem na zapas fazy (B). Sposób wyznaczenia nastaw regulatora PI metodą redukcji stałej czasowej (R) został szczegółowo omówiony w pracy (Cierpisz i Kaula 2013).

Parametry regulatora PI metodą bezpośrednią (B) zostały wyznaczone według następującego algorytmu:

Przyjęto wstępne założenie dotyczące postaci transmitancji układu zamkniętego:

$$
\mathrm{K}_{\mathrm{zam}}(\mathrm{s})=\frac{1}{\mathrm{~T}_{\mathrm{z}} \mathrm{s}+1} \mathrm{e}^{-\mathrm{s} \tau}
$$

$\Leftrightarrow \mathrm{T}_{\mathrm{z}}-$ zastępcza stała czasowa układu zamkniętego.

Strukturę regulatora wyznaczono z przekształcenia wzoru (3):

$$
\mathrm{K}_{\mathrm{R}}(\mathrm{s})=\frac{1}{(\mathrm{~K}(\mathrm{~s})+1)} \cdot\left(\frac{\mathrm{K}_{\mathrm{zam}}(\mathrm{s})}{1-\mathrm{K}_{\mathrm{zam}}(\mathrm{s})}\right)
$$

Rozwijając w szereg McLaurina opóźnienie czasowe, dla pierwszych wyrazów uzyskujemy:

$$
\mathrm{e}^{-\tau \mathrm{s}} \approx 1-\tau \mathrm{s}
$$

Wstawiając zależności (4) oraz (6) do równania (5):

$$
\mathrm{K}_{\mathrm{R}}(\mathrm{s})=\frac{(\mathrm{Ts}+1)}{\mathrm{k}(1-\tau \mathrm{s})} \frac{(1-\tau \mathrm{s})}{\left(\mathrm{T}_{\mathrm{z}}+\tau\right) \mathrm{s}}=\frac{\mathrm{T}}{\mathrm{k}\left(\mathrm{T}_{\mathrm{z}}+\tau\right)}\left(1+\frac{1}{\mathrm{Ts}}\right)
$$

Uzyskaliśmy strukturę regulatora PI

$$
\begin{gathered}
\mathrm{k}_{\mathrm{r}}=\frac{\mathrm{T}}{\mathrm{k}\left(\mathrm{T}_{\mathrm{z}}+\tau\right)} \\
\mathrm{T}_{\mathrm{i}}=\mathrm{T}
\end{gathered}
$$

W następnym kroku wyznaczamy parametr $\mathrm{T}_{\mathrm{z}}$. Parametr ten określono na podstawie warunków na zapas fazy $\Delta \phi$, według kryterium Nyquista: 


$$
\left\{\begin{array}{l}
\left|\mathrm{K}_{\mathrm{o}}\left(\mathrm{j} \omega_{\mathrm{g}}\right)\right|=1 \\
\arg \left\{\mathrm{K}_{\mathrm{o}}\left(\mathrm{j} \omega_{\mathrm{g}}\right)\right\}=-\pi+\Delta \phi
\end{array}\right.
$$

$\stackrel{\mathrm{K}_{0}}{\mathrm{O}}(\mathrm{j} \omega)$ - transmitancja widmowa wyznaczona na podstawie transmitancji operatorowej układu otwartego $\mathrm{K}_{\mathrm{o}}(\mathrm{s})=\mathrm{K}(\mathrm{s}) \mathrm{K}_{\mathrm{R}}(\mathrm{s})$ i podstawieniu $\mathrm{s} \rightarrow \mathrm{j} \omega$.

Transmitancja widmowa układu otwartego $\mathrm{K}_{\mathrm{o}}(\mathrm{j} \omega)$ dla nastaw (8) ma postać:

$$
\mathrm{K}_{\mathrm{o}}\left(j \omega_{\mathrm{g}}\right)=\frac{\mathrm{k}}{\mathrm{j} \omega \mathrm{T}+1} e^{-j \omega \tau} \frac{\mathrm{T}}{\mathrm{k}\left(\mathrm{T}_{\mathrm{Z}}+\tau\right)}\left(\frac{\mathrm{j} \omega \mathrm{T}+1}{\mathrm{j} \omega \mathrm{T}}\right)
$$

po uproszczeniu:

$$
K_{\mathrm{o}}\left(j \omega_{\mathrm{g}}\right)=\frac{e^{-j \omega \tau}}{\left(\mathrm{T}_{\mathrm{Z}}+\tau\right) j \omega}
$$

Zatem moduł i argument transmitancji widmowej przedstawiają wyrażenia:

$$
\begin{gathered}
\left|\mathrm{K}_{\mathrm{o}}(\mathrm{j} \omega)\right|=\frac{1}{\omega\left(\mathrm{T}_{\mathrm{z}}+\tau\right)} \\
\arg \left\{\mathrm{K}_{\mathrm{o}}\left(\mathrm{j} \omega_{\mathrm{g}}\right)\right\}=-\frac{\pi}{2}-\omega \tau
\end{gathered}
$$

Na podstawie warunków (9):

$$
\left\{\begin{array}{l}
-\frac{\pi}{2}-\omega_{\mathrm{g}} \tau=-\pi+\Delta \phi \\
\omega_{\mathrm{g}}=\frac{1}{\mathrm{~T}_{\mathrm{z}}+\tau}
\end{array}\right.
$$

otrzymujemy zależność parametru $\mathrm{T}_{\mathrm{z}}$ od zapasu fazy $\Delta \phi$.

Przyjmując zapas fazy $\Delta \phi=\frac{\pi}{3}$ (co zapewnia krótki czas narastania, przy małym przeregulowaniu), wartość parametru $\mathrm{T}_{\mathrm{z}}$ wynosi:

$$
\mathrm{T}_{\mathrm{Z}}=\frac{6-\pi}{\pi} \tau
$$


Po podstawieniu wyrażenia (15) do wzoru (8) nastawy regulatora PI są następujące:

$$
\begin{gathered}
\mathrm{k}_{\mathrm{r}}=0,52 \frac{\mathrm{T}}{\mathrm{k} \tau} \\
\mathrm{T}_{\mathrm{i}}=\mathrm{T}
\end{gathered}
$$

W tabeli 1 przedstawiono zależności wiążące wartości parametrów regulatora PI z parametrami transmitancji operatorowej obiektu dla zastosowanych metod doboru.

Tabela 1. Nastawy parametrów regulatora PI

\begin{tabular}{|c|c|c|}
\hline Metoda doboru nastaw & $\mathrm{k}_{\mathrm{r}}$ & $\mathrm{T}_{\mathrm{i}}$ \\
\hline Zieglera-Nicholsa (ZN) & $0,9 \frac{\mathrm{T}}{\mathrm{k} \tau}$ & $3,33 \tau$ \\
\hline $\begin{array}{l}\text { Redukcji stałej czasowej z warunkiem dotyczącym przebiegu } \\
\text { wielkości regulowanej }(\mathrm{R})\end{array}$ & $0,34 \frac{\mathrm{T}}{\mathrm{k} \tau}$ & $\mathrm{T}$ \\
\hline Bezpośrednia z warunkiem na zapas fazy (B) & $0,52 \frac{\mathrm{T}}{\mathrm{k} \tau}$ & $\mathrm{T}$ \\
\hline
\end{tabular}

Table 1. PI controller parameters settings

\section{Wyniki badań symulacyjnych}

$\mathrm{Na}$ podstawie zależności przedstawionych $\mathrm{w}$ tabeli 1 wyznaczono wartości nastaw parametrów regulatora PI (zależnych od parametrów $\mathrm{k}, \mathrm{T}, \tau$ modelu dynamiki obiektu) dla trzech metod doboru. Przeprowadzono badania symulacyjne odpowiedzi układu regulacji na skokową zmianę wielkości zadanej. Analizę przeprowadzono dla różnych wartości stosunku $\frac{\mathrm{T}}{\tau}$. W każdym z rozpatrywanych przypadków założono stałą wartość wzmocnienia obiektu $\mathrm{k}=1$. Wyniki przedstawiono graficznie.

Ponieważ analiza przeprowadzona jest dla liniowego modelu dynamicznego, reakcja układu regulacji (przebiegi przejściowe wielkości regulowanej) będzie analogiczna dla układu o parametrach T, $\tau$ wyrażonych w sekundach, jak i w minutach (ogólnie w dowolnych jednostkach czasu). Oś czasu t dogodnie jest przedstawić w jednostkach względnych (bezwymiarowo), gdyż dla stałej czasowej $\mathrm{T}$ i opóźnienia $\tau$, wyrażona w sekundach wartości na osi czasu, odpowiadają sekundom. Natomiast dla parametrów obiektu $\mathrm{T}$ i $\tau$ wyrażonych w minutach, na osi czasu wartości mają wymiar minut. 


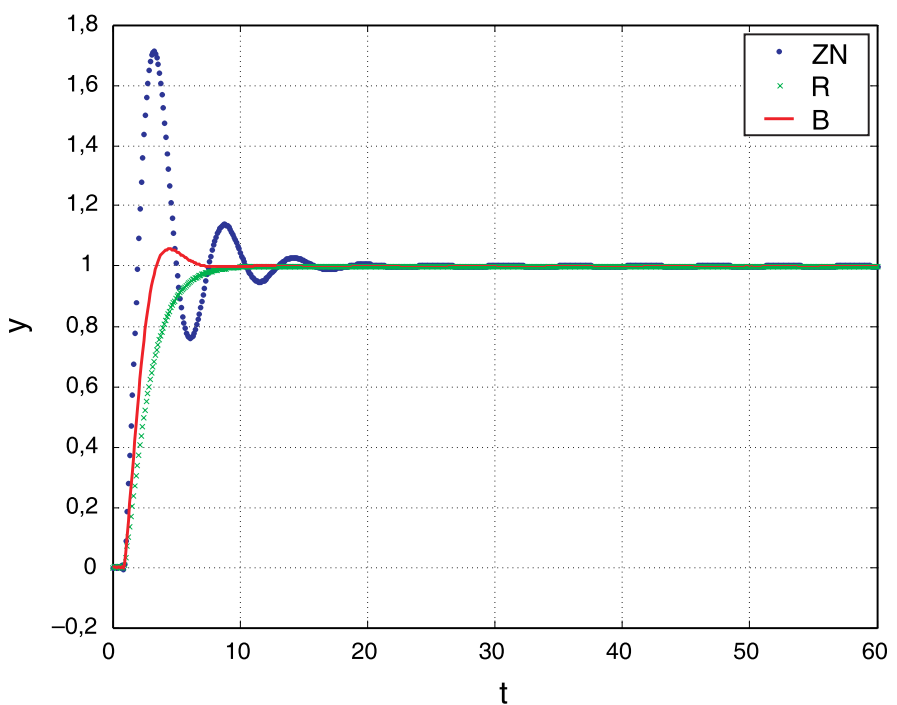

Rys. 2. Odpowiedź układu regulacji na skok jednostkowy dla $\frac{T}{\tau}=\frac{10}{1}$

Fig. 2. Response of the control system for unit step at $\frac{T}{\tau}=\frac{10}{1}$

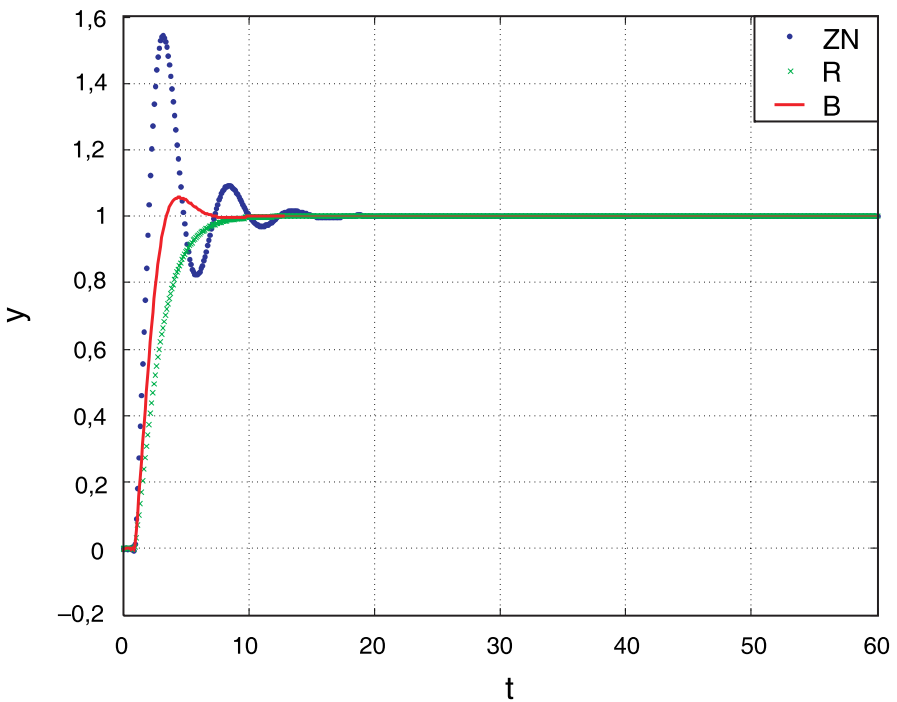

Rys. 3. Odpowiedź układu regulacji na skok jednostkowy dla $\frac{\mathrm{T}}{\tau}=\frac{5}{1}$

Fig. 3. Response of the control system for unit step at $\frac{T}{\tau}=\frac{5}{1}$ 


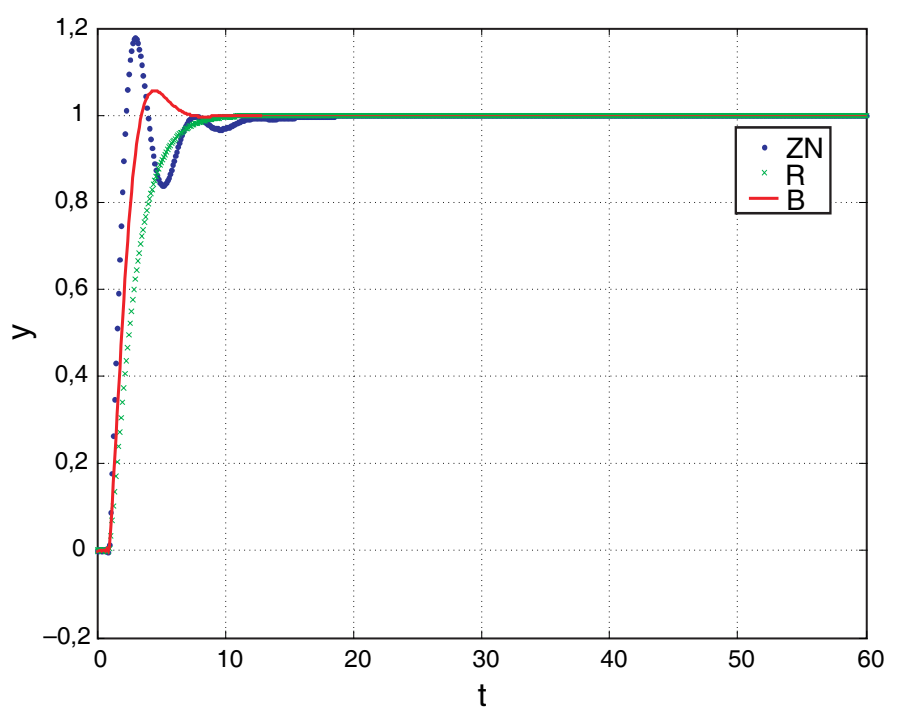

Rys. 4. Odpowiedź układu regulacji na skok jednostkowy dla $\frac{T}{\tau}=\frac{2}{1}$

Fig. 4. Response of the control system for unit step at $\frac{T}{\tau}=\frac{2}{1}$

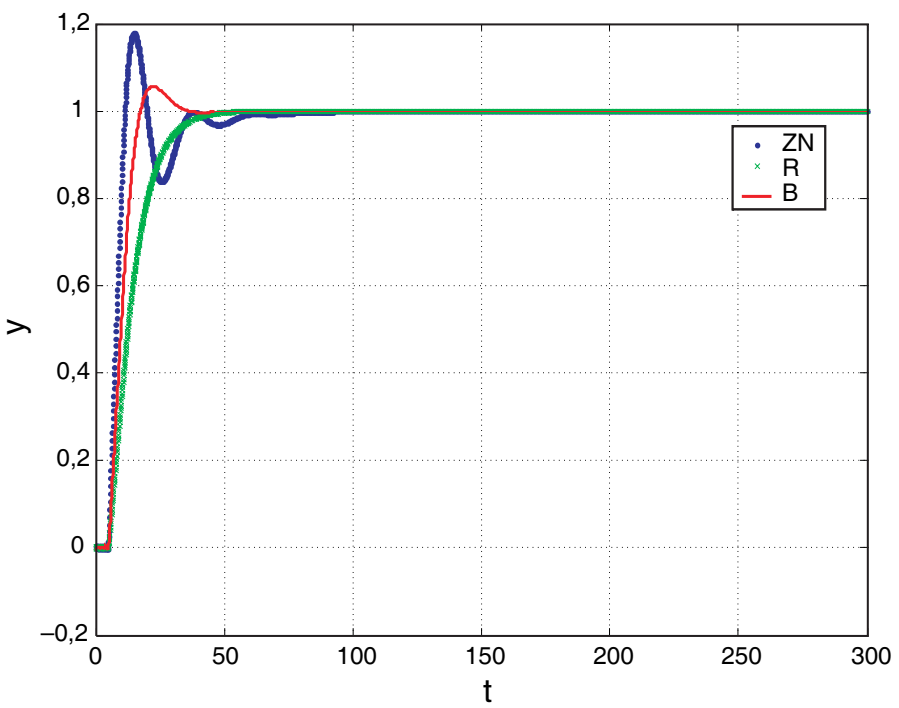

Rys. 5. Odpowiedź układu regulacji na skok jednostkowy dla $\frac{\mathrm{T}}{\tau}=\frac{10}{5}$

Fig. 5. Response of the control system for unit step at $\frac{T}{\tau}=\frac{10}{5}$ 


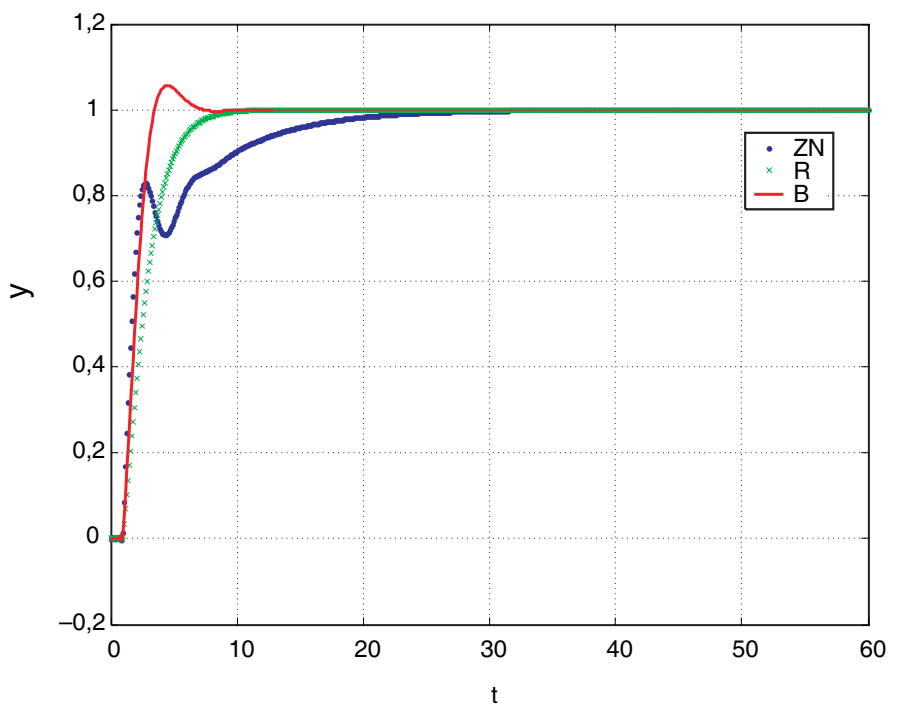

Rys. 6. Odpowiedź układu regulacji na skok jednostkowy dla $\frac{\mathrm{T}}{\tau}=\frac{1}{1}$

Fig. 6. Response of the control system for unit step at $\frac{\mathrm{T}}{\tau}=\frac{1}{1}$

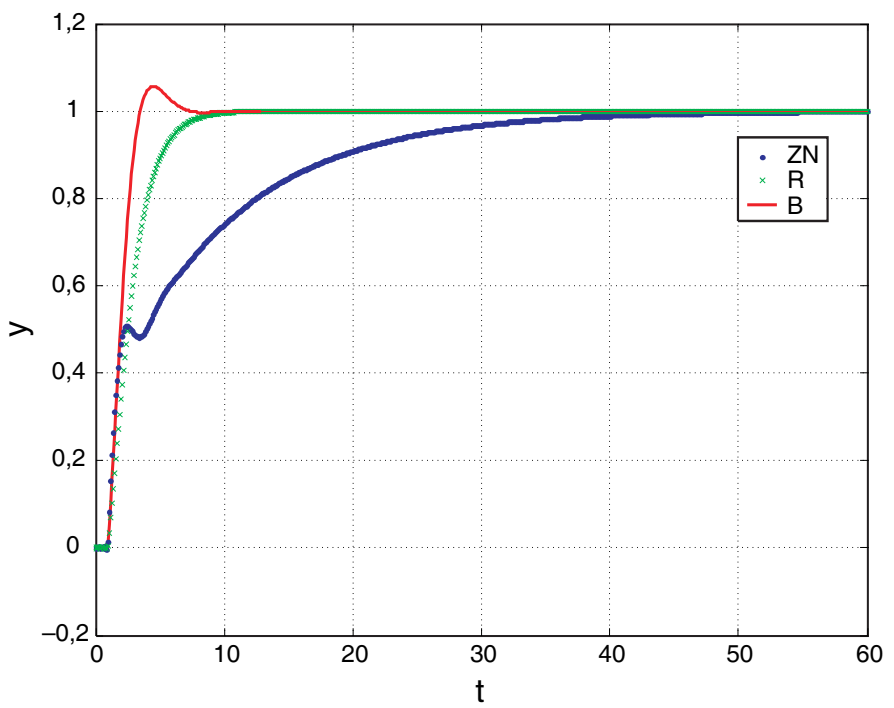

Rys. 7. Odpowiedź układu regulacji na skok jednostkowy dla $\frac{T}{\tau}=\frac{0,5}{1}$

Fig. 7. Response of the control system for unit step at $\frac{T}{\tau}=\frac{0,5}{1}$ 


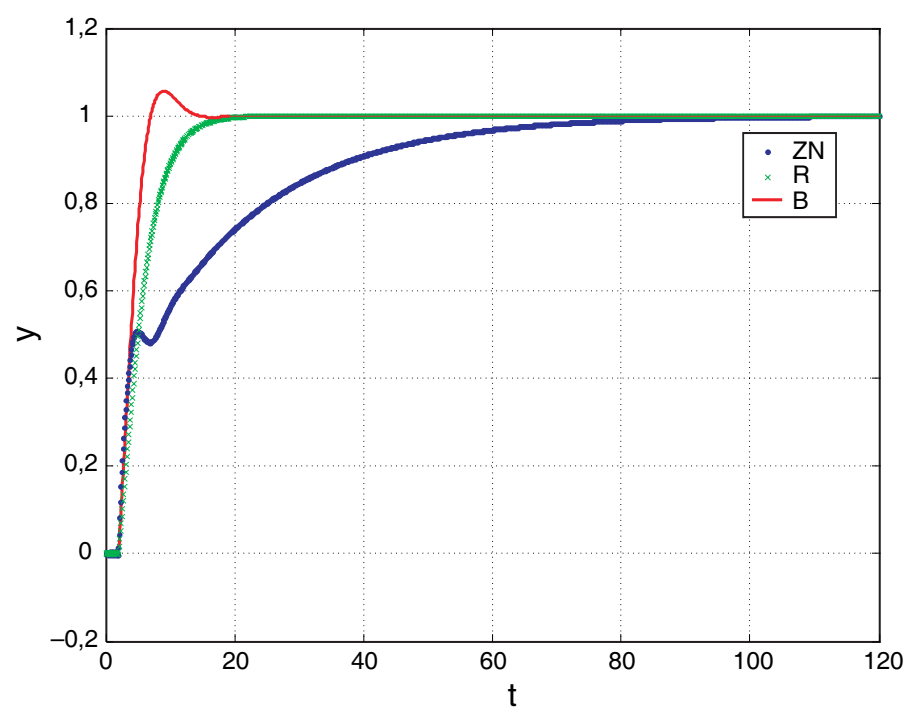

Rys. 8. Odpowiedź układu regulacji na skok jednostkowy dla $\frac{\mathrm{T}}{\tau}=\frac{1}{2}$

Fig. 8. Response of the control system for unit step at $\frac{\mathrm{T}}{\tau}=\frac{1}{2}$

\section{Podsumowanie}

W pracy przedstawiono wybrane metody doboru nastaw regulatora PI układów regulacji procesów, charakteryzujących się właściwościami dynamicznymi obiektu inercyjnego z opóźnieniem. Przeprowadzono analizę jakości regulacji dla nastaw regulatora wyznaczonych powszechnie stosowaną metodą Zieglera-Nicholsa i dwiema innymi metodami doboru nastaw regulatora PI. Rozważania przeprowadzono dla różnych wartości stałej czasowej $\mathrm{T}$ i opóźnienia $\tau$ obiektu. Odpowiedzi układu regulacji, dla nastaw regulatorów wyznaczonych zgodnie ze wzorami z tabeli 1, otrzymano dla skokowej zmiany wartości zadanej. Z przebiegów (rys. 2-8) można zauważyć, że dla nastaw według kryterium Z-N, charakter przebiegów wielkości regulowanej znacznie się zmienia w zależności od wartości parametrów $\mathrm{T}$ i $\tau$ oraz ich stosunku. Im stosunek $\mathrm{T} / \tau$ jest większy, tym występują większe oscylacje wielkości regulowanej (rys. 2-4). Dla stosunku $\mathrm{T} / \tau<1$ zanikają oscylacje, natomiast wydłuża się czas ustalania przebiegu wielkości regulowanej. Dla różnych wartości $\mathrm{T}$ i $\tau$, ale tego samego stosunku $\mathrm{T} / \tau$ (rys. 4 i 5 oraz odpowiednio rys. 7 i 8 ), charakter przebiegu przejściowego jest taki sam. Różnice związane są z czasem trwania przebiegu przejściowego (czasem ustalania) i wynikają z opóźnienia $\tau$.

Porównując wyniki regulacji dla nastaw regulatora według metody redukcji (R) i metody bezpośredniej (B), można zauważyć taki sam charakter przebiegów przejściowych, 
niezależnie od wartości stałej czasowej i opóźnienia. Dla układu regulacji z nastawami, według metody bezpośredniej (B), uzyskano najkrótszy czas ustalania przebiegu przejściowego i krótki czas narastania, natomiast występuje małe przeregulowanie. Dla układu regulacji, według metody redukcji (R), czas narastania jest dłuższy, czas ustalania przebiegu przejściowego jest porównywalny do metody bezpośredniej. Nie występuje natomiast przeregulowanie (przebieg przejściowy o charakterze aperiodyczno krytycznym).

Odpowiedni charakter przebiegu przejściowego (tym samym wskaźników jakości regulacji), w metodach bezpośredniej i redukcji, uzyskuje się przez przyjęcie parametru regulatora całkującego równego stałej czasowej obiektu $T_{i}=T$. Identyfikacja parametrów obiektu (w tym stałej czasowej) w warunkach przemysłowych realizowana jest zwykle w trakcie normalnej eksploatacji (z oddziaływaniem zakłóceń), tym samym wyznaczone parametry modelu dynamicznego mogą się różnić od wartości rzeczywistych procesu. Zatem w dalszych badaniach należy przeprowadzić analizę wpływu zmian parametrów modelu obiektu na przebieg wielkości regulowanej. Dla nastaw regulatora wyznaczonych według parametrów $\mathrm{T}$ i $\tau$ należy przeprowadzić badania na obiekcie o parametrach $\mathrm{T} \pm \Delta \mathrm{T}$ oraz $\tau \pm \Delta \tau$. Dogodnym narzędziem takich badań jest analiza wrażliwości.

\section{LITERATURA}

Cierpisz, S. 1980. Automatyzacja procesów przeróbki mechanicznej węgla. Wyd. „Śląsk”, Katowice.

Cierpisz, S. 2003. Układy sterowania procesem produkcji mieszanek węgla z regulowanym przepływem jednego składnika. Materiały Konferencyjne IX Konferencji Automatyzacji Procesów Przeróbki Kopalin, Szczyrk, czerwiec 2003, s. 49-60.

Cierpisz, S. 2012. Automatyczna regulacja procesu wzbogacania w osadzarkach. Wydawnictwo Politechniki Śląskiej, Monografia Nr 403, Gliwice.

Cierpisz, S. i Kaula, R. 2013. Dobór parametrów regulatora dla obiektu inercyjnego z opóźnieniem na przykładzie osadzarki pulsacyjnej. Materiały Konferencyjne Konferencji „Nowoczesne rozwiązania z zakresu procesów technologicznych przeróbki węgla”, wydane przez Instytut Technik Innowacyjnych EMAG, Zakopane, maj 2013.

Joostberens, J. 2011. Modele dynamiczne procesu flotacji węgla wyznaczone przy użyciu metody zmiennej instrumentalnej. Mechanizacja i Automatyzacja Górnictwa nr 12, s. 34-37.

Kalinowski, K. 1991. Sterowanie procesu flotacji węgla. Wydawnictwo Politechniki Śląskiej, Gliwice.

Kalinowski, K. i Kaula, R. 2000. Dynamika zmian zawartości popiołu w odpadach w badaniach eksperymentalnych flotacji węgla. Mechanizacja i Automatyzacja Górnictwa nr 1, s. 35-40.

O’Dwyer, A. 2003. Handbook of PI and PID controller tuning rules. Imperial College Press, London.

Ziegler, J. i Nichols, N. 1942. Optimum settings for automatic controllers, Trans. ASME, vol. 64, p. $759-768$.

PN-88/M-42000. Automatyka i pomiary przemysłowe. Terminologia. 
DOBÓR NASTAW REGULATORA PI W UKŁADACH REGULACJI PROCESÓW WZBOGACANIA WĘGLA

\author{
Słowa kluczowe
}

wzbogacanie węgla, dynamika obiektu, układy regulacji procesów wzbogacania węgla, metody doboru nastaw regulatora PI

\title{
Streszczenie
}

Jednym z podstawowych zadań układów regulacji procesów wzbogacania węgla jest stabilizacja parametrów jakościowych na zadanym poziomie. Sterowanie procesów technologicznych wzbogacania węgla odbywa się w obecności szeregu zakłóceń. Zatem istotnym problemem jest wybór regulatora odpornego na różnorodne zakłócenia. Regulatory PI oraz PID są stosowane w wielu procesach przemysłowych. Szerokie zastosowanie tych regulatorów wynika z wielu zalet, którymi się charakteryzują. Najważniejsze z nich to dobre właściwości kompensacji zakłóceń występujących w procesach przemysłowych oraz prosta budowa tych regulatorów (a zatem łatwa implementacja). Wybór struktury PI albo PID regulatora zależy od właściwości dynamicznych sterowanego procesu, zakłóceń oddziałujących na ten proces oraz wymagań stawianych układowi regulacji. Ze względu na szereg zakłóceń występujących w procesach przeróbczych węgla stosowanie członu różniczkującego regulatora PID powinno być ograniczone, na przykład do stabilizacji wybranych parametrów w sterowaniu lokalnym. Celowym rozwiązaniem wydaje się zastosowanie struktury PI regulatora w układzie regulacji. Nie mniej ważnym zagadnieniem w regulacji procesu jest dobór nastaw regulatora. W wielu metodach doboru nastaw regulatora wykorzystuje się charakterystyki dynamiczne sterowanego procesu (model dynamiczny obiektu sterowania). Opis właściwości dynamicznych procesu za pomocą modelu matematycznego jest pomocny przy projektowaniu układu sterowania. Różne procesy charakteryzujące się takimi samymi właściwościami dynamicznymi można opisać modelem dynamicznym o takiej samej strukturze, różniącym się tylko wartościami parametrów. Takie podejście daje możliwość zastosowania tego samego typu regulatora w układach regulacji różnych procesów przemysłowych. Odnosi się to także do wielu procesów wzbogacania węgla.

Wyniki badań dotyczących dynamiki procesu flotacji węgla były przedstawione w wielu pracach (Joostberens 2011; Kalinowski 1991; Kalinowski i Kaula 2000). Na ich podstawie można stwierdzić, że dynamika procesu flotacji dla obiektu o jednym wejściu sterującym (natężenie przepływu odczynnika flotacyjnego) oraz jednym wyjściu (zawartość popiołu w odpadach flotacyjnych), może być przedstawiona za pomocą modelu o właściwościach elementu inercyjnego z opóźnieniem czasowym. Przyjmuje się, że funkcje przejścia podstawowych sygnałów osadzarki można także opisać za pomocą elementu inercyjnego pierwszego rzędu z opóźnieniem (Cierpisz 1980, 2012). Na przykład charakterystykę dynamiczną strefy odbioru produktu dolnego. Wielkością wyjściową jest gęstość rozdziału w osadzarce natomiast wielkością wejściową natężenie przepływu produktu dolnego. Analogicznego opisu można dokonać w procesie produkcji mieszanek węgla z dwóch składników: koncentratu o określonej zawartości popiołu i węgla surowego. W układzie tym wielkością wyjściową jest zawartość popiołu w mieszance, a wielkością wejściową natężenie przepływu węgla surowego. Z punktu widzenia dynamiki omawiany układ technologiczny (Cierpisz 2003) jest szeregowym połączeniem członu inercyjnego (odpowiednio dozowane składniki mieszanki) i opóźnienia transportowego (transport materiału na przenośniku taśmowym). 
W artykule przedstawiono trzy metody doboru nastaw regulatora PI układów regulacji procesów wzbogacania węgla charakteryzujących się właściwościami dynamicznymi obiektu inercyjnego z opóźnieniem. Dokonano porównania wyników regulacji stabilizacyjnej dla nastaw regulatora PI, wyznaczonych: klasyczną metodą Zieglera-Nicholsa (ZN), metodą redukcji stałej czasowej z warunkiem dotyczącym przebiegu wielkości regulowanej $(\mathrm{R})$ oraz metodą bezpośrednią z warunkiem na zapas fazy (B). Sposób wyznaczenia nastaw regulatora PI metodą redukcji stałej czasowej (R) został szczegółowo omówiony w pracy (Cierpisz i Kaula 2013). Parametry regulatora PI metodą bezpośrednią (B) zostały wyznaczone według algorytmu szczegółowo opisanego w artykule. Rozważania przeprowadzono dla różnych parametrów obiektu, na podstawie odpowiedzi układu regulacji dla stałej wartości wielkości zadanej. W podsumowaniu dokonano oceny rozpatrywanych metod doboru w odniesieniu do wybranych wskaźników jakości regulacji.

\section{PI CONTROLLER TUNING IN CONTROL SYSTEMS OF THE COAL ENRICHMENT PROCESSES}

$$
\text { Key words }
$$

coal enrichment, dynamic model, control systems of coal enrichment process, tuning methods of PI controller parameters

\section{Abstract}

One of the main tasks of control systems of coal enrichment process is the stabilization of coal quality parameters at a desired level. The control of coal enrichment processes is carried out in the presence of a number of disturbances. Therefore, a serious problem is the controller selecting which is robust to different disturbances. Controllers PI (proportional-plus-integral) and PID (proportional-plus-integral-plus-derivative) are used in many industrial processes. Extensive uses of PID controllers is results from a number of advantages that characterizes. The most important of them is good compensation of disturbances occurring in industrial processes and simple design of these controllers (therefore easy to implement). Selection of PI or PID controller structure depends on the dynamic properties of the controlled process and disturbances influencing to the process and the requirements for the control system. Due to a number of disturbances occurring in the coal preparation processes the application of a derivative element should be limited, for example, to stabilize the selected parameters in local control. The better solution seems to use the structure of PI controller in the control system. No less important problem in the control of the process is the tuning of the controller parameters. Many methods of tuning of the controller parameters uses the dynamic characteristics of the controlled process (dynamic model of the process). The description of the dynamic properties of the process by means of a mathematical model it is helpfully in the design of the control system. Different processes with the same dynamic properties can be described by a dynamic model of the same structure, differing only parameters values. Such approach makes it possible to use the same type of controller in control of various industrial processes. This is also relates for many coal enrichment processes.

The results of the dynamics of coal flotation process in a number of papers (Joostberens 2011; Kalinowski 1991; Kalinowski and Kaula 2000) were presented. On this basis it can be concluded that 
the dynamics of the flotation process for the controlled system with controlling input (flow rate of flotation reagent) and controlling output (the ash content in the tailings) may be represented by a model of the inertial element properties with time delay. It is assumed that the transfer functions of basic jig signals can also be described by first-order inertial element with time delay (Cierpisz 1980, 2012). For example, the dynamic behavior of the reception zone of the underflow in the jig can be described by this model, wherein the output signal is the density distribution in the jig and the input flow rate of underflow is the input signal. Let consider the process production of coal blends from two components: a concentrate and raw coal. In this system the ash content in the blend is the output signal while the intensity flow rate of raw coal is the input signal. From the point of view of the dynamics described technological system (Cierpisz 2003) is the inertial element (properly dosed components of the blend) with time delay (transport of material on the conveyor belt).

This paper presents three methods of tuning of PI controller parameters for control system of coal preparation processes that are characterized by dynamic properties of the inertial element with time delay. The tuning method of PI controller parameters for the classical Ziegler-Nichols method (ZN), the method of reducing of time-constant $(\mathrm{R})$ and the direct method $(\mathrm{B})$ were presented. Method of determining the PI controller settings by reducing the time-constant $(\mathrm{R})$ was discussed in detail in the paper (Cierpisz and Kaula 2013). PI controller parameters using the direct method (B) were calculated according to the algorithm described in detail in this paper. The results of comparison analysis of the control system with PI controller parameters were presented. The analyses were carried out based on the response of the control system on constant set point for various parameters of the dynamic model. The analysed tuning methods of PI controller parameters for selected indices of control quality have been evaluated. 